\title{
The Link between Entrepreneurship Education and Business Success: Evidence from Youth Entrepreneurs in South Africa
}

\author{
Saphetha Appie Gwija ${ }^{1}$, Chuks Eresia-Eke ${ }^{2}$ and Chux Gervase Iwu ${ }^{3}$ \\ ${ }^{1}$ Faculty of Business, Cape Peninsula University of Technology, South Africa \\ E-mail: sgwija@gmail.com \\ ${ }^{2}$ Department of Business Management, University of Pretoria, South Africa \\ E-mail: chuks.eresia-eke@up.ac.za \\ ${ }^{3}$ Faculty of Business, Cape Peninsula University of Technology, South Africa \\ E-mail: iwuc@cput.ac.za / chuxiwu@gmail.com
}

\begin{abstract}
KEYWORDS Entrepreneurship Education. Youth Entrepreneurial Ventures. Khayelitsha. South Africa. Entrepreneurial Intention

ABSTRACT The aim of this study was to find out whether youth entrepreneurs in a South African township consider entrepreneurship education and training as a useful vehicle for navigating the challenging waters of entrepreneurship. The method used to collect data was a self-administered questionnaire. Findings revealed that the participants thought of entrepreneurship education and training as a viable tool for entrepreneurship development. The study recommends further research on other townships with similar characteristics to enable a better understanding of the unique needs of the different townships. This is on the basis that should an intervention be proposed, each township should then have a much more customised training and development strategy.
\end{abstract}

\section{INTRODUCTION}

Entrepreneurship is considered as the most common powerful economic force across the globe (Kuratko 2014) and as a result the inability of many young people in the globe to access paid employment during and after they have graduated calls for the need for entrepreneurship education and training because of its capacity to enable business start-up and management (Keat et al. 2011). Many institutions of higher learning (universities and colleges) around the world have therefore responded to this demand by developing entrepreneurship courses with the primary intention of fostering entrepreneurial mindset (Postigo and Tamborini 2002). South Africa is no different according to Van Rensburg (2010) who affirmed that South African schools offer entrepreneurship education from as early as primary school. This affirmation seems to contradict critics of the education system who are of the opinion that the throughput rate within the discipline of entrepreneurship is dismal (Western Cape Youth Report 2008). This critique leads one to ask whether the education system is at fault or whether some other factor is responsible. One could even implicate poor funding of the education system or something else.

Corresponding author:

E-mail: sgwija@gmail.com
But if one looks at the education budget in South Africa, one is convinced to think differently. This is because education is among major categories, in which government continues to substantially spend more, with the recent spending of R207 billion in 2012/13 and the expected growth, which will amount to R236 billion in 2014/15's financial year period (Gordhan 2012). Perhaps, this can be looked at as an optimistic manifestation that the government is indeed taking education seriously. In addition, this should also encourage South Africa's youth to acquire education, and in particular pursue entrepreneurial careers so that they can gain the necessary intellectual, psychological and practical skills of entrepreneurship, which are essential in the everchanging socio-economic landscape and in the business world. Nafukho and Muyia (2009) believe that investing in entrepreneurship education and training is one of the best strategic approaches, which any country may pioneer to advance its human capital, and consequently aid socio-economic development.

Similarly, James (2012) maintains that during the current era of job-scarcity in South Africa, where a number of traditional industries are reluctant to employ young graduates, fostering youth entrepreneurship could be the answer to the unemployment agenda. Perhaps this can be linked to Ndedi's (2009) assertion that, in the past few decades, the United States has experi- 
enced an upsurge in entrepreneurship because of the emergence of training centres and higher education institutions, which offer entrepreneurship courses. Perhaps this is the reason why numerous African countries have also acknowledged entrepreneurship as a mechanism to address the unemployment problem (Nafukho and Muyia, 2009), which was recently estimated at 70 percent, among the youth in South Africa (Fatoki and Chindoga 2011; Mkoka 2012). This could mean that a majority of young people in South Africa live in impoverished conditions, which may result in low standards of living (Fatoki and Chindoga 2011); intention to commit crime (Mahadea et al. 2011; Mkoka 2012), low self-esteem, which could result in a negative outlook to life (Fatoki and Chindoga 2011). The persistence of this situation may not auger well for the poor, as the next generation may have no choice but to bear the poverty legacy. What disheartens more is Morrow et al. (2005) caution, that poverty has a tendency of reproducing itself among children and the young people who come from already disadvantaged backgrounds.

Thus, the importance of the emergence and sustainability of entrepreneurship development, particularly among the youth is indisputable. Significantly, Nicolaides (2011) affirms that entrepreneurs are the ones who use their creativity and innovation to fabricate new technologies, products and services, to meet society's needs. He adds that entrepreneurs are capable of transforming the socio-economic landscape, through the creation and exploitation of new opportunities in the market. Disappointingly though, in South Africa, young people lag behind in setting up own businesses compared to their counterparts from other countries (Von Broembsen et al. 2005). This however does not paint a good picture for young people's economic participation, and may result in young people being more dependent on the state's limited budget (Herrington et al. 2009), as it usually invests more of its resources on the youth through education, health and social grants (Gordhan 2012; Mkoka 2012). A rather disturbing revelation was also made by Shay and Wood (2004). They found that Black South Africans lack self-confidence to start-up a business, compared to their counterparts in Argentina, India, Brazil, and Mexico. Therefore better approaches need to be identified in order to motivate South Africa's youth to engage in entrepreneurship education and training, primarily for the purpose of becoming entrepreneurs (job-creators), particularly in the current job-scarce environment in the country. Hence, Nafukho and Muyia (2009) believe that investing in entrepreneurship education and training is one of the best strategic approaches, which may capacitate and advance human resources in order to promote socio-economic development of a country. Kume et al. (2013:206) also emphasize entrepreneurship education as a solution to the unemployment problem, especially for university graduates. Perhaps the ideal that entrepreneurship should be incorporated into other subjects at tertiary environment should be closely observed. This is of critical importance, in particular since in South Africa it appears that more and more entrepreneurship graduates opt for paid jobs instead of creating their own jobs.

The foregoing is the background against which this study was conceived. Thus, we pose the following question: How do youth entrepreneurs perceive entrepreneurship education and training as a vehicle for the success of their business ventures? The relevance of this question can be found in a World Bank (2006) report which affirmed that majority of people who escape from poverty do so by starting their own business or finding work in an existing one. South Africa's current unemployment rate therefore necessitates practical teaching and learning of entrepreneurship skills to enable the acquisition of requisite skills for job creation and self-employment. Awogbenle and Iwuamadi (2010) seem to be in agreement. They affirm that entrepreneurship is increasingly accepted as an important means and valuable additional strategy to create jobs and improve livelihoods and economic independence of young people. Since training in effective business development services has been reported as a possible panacea for some of the challenges that entrepreneurs confront, youth entrepreneur's perception of entrepreneurship education and training will indeed provide some insight into stimulating training and development strategies for youth entrepreneurs. Considering the objective of this study, we define business success as the realization of worthy intentions by a business (Xesha et al 2014). These intentions could be improved profits, increased assets, expansion, and all other factors signaling growth and development of the business. 
This study is set in South Africa; in one of its largest townships named Khayelitsha. Khayelitsha is dominated by Xhosa speaking Black South Africans. The township's less advantaged socio-economic background is attributed to the imbalances posed by the Apartheid regime that also established it back in the early 1980s. The study will likely provide some direction in terms of understanding the uniqueness of this large township and its potential for youth entrepreneurship development.

\section{Literature Review}

Entrepreneurship Education and Training: Entrepreneurship education has been defined in various ways by various scholars and practitioners. The interesting thing about the various definitions is the similarity they share. For instance, the Centre for Entrepreneurial Clearinghouse defines it as 'the process of providing individuals with the concepts and skills to recognise opportunities that others have overlooked, and to have the insight, self-esteem and knowledge to act where others have hesitated. The Nigerian Education Research and Development Council (NERDC) (2004) consider entrepreneurship education as a comprehensive term referring to those aspects of the educational process involving, in addition to general education, the study of technology related sciences and the acquisition of entrepreneurial skills, attitudes, understanding, and knowledge relating occupations in various sectors of economic and social life.

Isaacs et al. (2007) define entrepreneurship education as the purposeful intervention that is made by an educator in the life of the learner through entrepreneurial qualities and skills teaching, which will enable the learner to survive the dynamics of the business world. Mwangi (2011) believes that entrepreneurship education is designed to specifically support graduates, operating and aspirant entrepreneurs in the setting up/operation of their own entrepreneurial ventures rather than to seek paid employment from someone else or institutions (either public/private). Hence, Mensah (2013) adds that entrepreneurship education may capacitate an individual to unleash his/her entrepreneurial potential.
This paper adopts the definition of Isaacs et al. (2007) because it encapsulates the objectives of entrepreneurship education which are to develop entrepreneurs and foster entrepreneurial mind-set among learners, with the help of the right learning processes (Mwangi 2011). This paper also finds value in Thomas and Barra's (1994) explanation that entrepreneurship education and training programmes comprise the following objectives:

- the acquisition of knowledge and skills that are relevant to entrepreneurship;

- the identification, exploration and fuelling of entrepreneurial drive, talent and skills;

- undoing the risk-averse bias of many analytical procedures;

- developing understanding and support for all unique facets of entrepreneurship;

- the development of positive attitudes towards change; and

- to encourage new start-ups and other existing entrepreneurial ventures.

Albert et al. (2004) claim that entrepreneurship education can be traced back to 1938 when Shigeru Fijii, taught and in fact introduced entrepreneurship education at Kobe University in Japan. Nonetheless, the United States has established a large number of colleges and universities (with more than 1500), which offer entrepreneurship and small business management courses and programmes (Keat et al. 2011). This aligns with Katz's (2003) earlier assertion that, since the introduction of the first entrepreneurship class at Harvard's Business School, in the United States in 1947, the number of American students taking entrepreneurship or small business courses has drastically been on the increase. He further argues that as a result of this $20^{\text {th }}$ century's history of entrepreneurship education, the economies turned to America for inspiration. He nevertheless points out that this might not be the case in the $21^{\text {st }}$ century (see Katz 2003). Ndedi (2009) also agrees that the United States's proliferation of entrepreneurship is attributed to the abundance of training centres and higher education institutions, which offer entrepreneurship courses. Iqbal et al. (2012) agree that entrepreneurship education and training has caught the attention of many universities in the world, including African countries, as it is part of their curricula. Perhaps this is influenced by a speedy emergence and diffusion of entrepreneurship policies, which appear to be 
of concern across the globe, in particular the developed countries, in the last few decades (Mensah 2013).

A South African Perspective of Entrepreneurship Education and Training: The legacy of Apartheid and inferior quality education that was provided to Black South Africans in the country meant that most of them would have very limited opportunities to acquire qualities and skills that can enable the setting up of and successful management of an entrepreneurial venture (Nicolaides 2011). Nonetheless, since the early 1990s, entrepreneurship education has gained popularity in South Africa, especially since Higher Education Institutions (HEIs) introduced entrepreneurship programmes and courses (Jesselyn Co and Mitchell 2006). This, according to Davies (2001), was stimulated by the dismal downturn in South Africa's capacity to absorb new recruits into the formal sector. Thus, the entrepreneurship education approach had the objective of developing job-creators who would take calculated risks, break new grounds and innovate, instead of job-seekers who might find themselves joining the army of the unemployed, after having graduated or left tertiary schooling environment (Jesselyn Co and Mitchell 2006; Nieuwenhuizen and Groenewald 2008).

HEIs are a powerful force, which can be used to influence entrepreneurial attitudes among the youth through the inculcation of appropriate knowledge regarding aspects such as risks and rewards, opportunity seeking and recognition skills, creation and nurturing of entrepreneurial venture (Jesselyn Co and Mitchell 2006). In addition, the HEIs should include entrepreneurial traits that can be thought and learned. These include creativity and innovation, passion, willingness to take calculated risks, self-confidence, determination and perseverance, need for independence, persuasiveness, tolerance for uncertainty and ambiguity, imagination, high need for achievement, internal locus of control, and so on (Nieman et al. 2003; Burke 2006; Nieman and Nieuwenhuizen 2009).

Research indicates that, in South Africa, entrepreneurship education is being offered within several HEIs in the form of entrepreneurship diplomas and degrees or integrated in courses (Ndedi 2009). Evidence of this are GIBS Fulltime Entrepreneurship MBA; University of Pretoria; University of South Africa; UCT Centre for Innovation and Entrepreneurship (CIE) at the
Graduate School of Business (GSB); University of Johannesburg; WITS Business School (WBS); Cape Peninsula University of Technology (CPUT) (Van Rensburg 2010).

Ndedi (2009) however suggests that in order to effectively address the demand for more entrepreneurs in South Africa, business incubators need to be established in universities to assist students to link theoretical training to practical exposure. He adds that incubators could provide management guidance and technical assistance to learners and youth entrepreneurs in any business related issues. Furthermore, he also suggests that at the university setting, entrepreneurship must be introduced in all disciplines, and implemented at all levels. This suggestion seems to be in agreement with Lowergren (2006) argued that social sciences, engineering, information and design, and many other disciplines, may also require the same skills as those of entrepreneurial students. Hence, opportunity recognition may not only occur for a business student, but also for students from other disciplines (Ndedi 2009). This relates to Burke's (2006) assertion that entrepreneurs can be found in all walks of life.

Pittaway and Cope (2007) in Davey et al. (2011) are of the opinion that university education may have an influential role in persuading young people's attitudes towards entrepreneurship, especially within the South African context (Isaacs et al. 2007) Sandrock (2011) therefore opines that university graduates, as well as matriculants will benefit from proper entrepreneurial skills, so as to create more jobs, as opposed to seeking for a paid job. She stresses that South Africa needs a generation of employers and not a generation of employees.

Areas of Entrepreneurship Education: According to Laukkannen (2000) and Postigo and Tamborini (2002), there are two areas of entrepreneurship education which a variety of teaching methods may be used respectively. These are (1) Education entrepreneurship, which addresses construct and transference of knowledge about the field (Laukkannen, 2000); and (2) Education for entrepreneurs, which deals with learning experience and development of competencies/skills and values (Postigo and Tamborini 2002). In the case of Postigo and Tamborini's (2002) areas of entrepreneurship education, techniques that are frequently used include: consulting services by students and researches, 
whilst educating for entrepreneurship makes use of such methods as: videos, practical work, writing business plans, computer simulations, role playing games, working with entrepreneurs, and joining a students' entrepreneurial club. As far back as 1993, Klant suggested the following techniques: reading, lectures, guest speakers, case studies, on-site visits, and workshops. Perhaps the combination of both these methods can be used to effect positive results in the learner's well-being. Nonetheless, in the context of South Africa, no studies can be found, which investigated teaching methods of entrepreneurship education, from primary to tertiary school level.

Researchers in the field of entrepreneurship agree that more attention should be paid to entrepreneurship education and training rather than to business education because of its limited coverage as opposed to entrepreneurship education and training, which has additional topics (Isaacs et al. 2007). Research indicates that entrepreneurship education is a life-long learning process, which according to the association of educators and other stakeholders that support youth entrepreneurship education in the United States (Consortium for Entrepreneurship Education) comprises five stages, namely, basics, competency awareness, creative applications, start-up, and growth (Macaulay 2008). At the basic stage, entrepreneurs should be provided with prerequisite skills such as identifying career options; understanding economics and free enterprise. At the competency awareness stage, they are trained to discover entrepreneurship competencies as well as an understanding of the problems of employers. At the creative applications stage, they learn entrepreneurship competencies, apply specific occupational training and then learn how to create new businesses. It is expected that at the start-up stage, the apprentice entrepreneur becomes self- employed; develop policies and procedures for a new or existing business. Finally, during the growth stage, he is able to solve business problems effectively and possibly expand an existing business.

It is however uncertain whether the South African schools/universities do pursue the same five stages in their entrepreneurship education curricula.

Value of Entrepreneurship Education and Training: Entrepreneurship education is vital for socio-economic landscape, as it could play an influential role in equipping and changing ones attitude to become an entrepreneur (Peterman and Kennedy 2003; Volery and Mueller 2006 in Keat et al. 2011). Similarly, in the study conducted by Owusu-Ansah and Fleming (2002), it was noted that entrepreneurship training is crucial to the success of a business venture (Nieuwenhuizen and Groenewald 2008). Hence, Ladzani and Van Vuuren (2002) propose that entrepreneurship training should be considered among basic requirements of setting up and managing a business.

Research indicates that economies, particularly the industrialised, acknowledge entrepreneurship education and training, as the vital force to the economic growth of a country, through its influence in the emergence and sustenance of entrepreneurial ventures Isaacs et al. 2007) emphasize that even though in isolation, education cannot completely equip entrepreneurs to be successful business owners; it (education) however increases their chances of success in a business.

Nieuwenhuizen and Groenewald (2008) argue that an entrepreneurial culture should begin at home, from a family business and further develop to higher education and training institutions. Isaacs et al. (2007) expand on this viewpoint by saying that the key to the success of the emergence of a culture of entrepreneurship through education is for all stakeholders - government, educators, learners - to become active participants. Nevertheless, kick-starting an entrepreneurial culture from home, for many young people, in particular Blacks South Africans might not be as easy for the majority because of their poor backgrounds, resulting in very limited opportunities to access entrepreneurial exposure.

Managerial Competencies of an Entrepreneur: Burke (2006) argues that entrepreneurship comprise a number of knowledge areas (such as small business managerial, project managerial, and emotional intelligence skills), which may play a fundamental role in managing an entrepreneurial venture successfully. In other words, entrepreneurial skills in isolation may not result in achieving the optimum performance of a business venture. Nonetheless, for the purpose of this study more attention is paid to two knowledge areas that appear to be the most important in a performance of the business venture, which Van Rensburg (2011) also argues that an entrepreneur should focus on developing for proper 
entrepreneurial performance. These knowledge areas are briefly discussed below.

- Managerial Skills: Entrepreneurial ventures differ in size, type and structure, including their functions, which may include operations, finance, marketing, administration, and so on. Each function in the business needs a manager, who may also be the business owner (an entrepreneur) that should possess general managerial skills, such as planning, organising, leading and controlling business resources (Nieuwenhuizen et al. 2008). Burke (2006) suggests that entrepreneurs should consider a number of management techniques in their portfolio of managerial skills in order to effectively manage a new or existing business venture. These include project management, small business management, team building and leadership, and risk management skills.

- Entrepreneurial Skills: Nicolaides (2011) describes entrepreneurs as savvy risk takers, implementers and innovators who can transform a socio-economic landscape through the creation and exploitation of new opportunities in the market. Back in 1986, research conducted by McClelland and McBer and Company identified three categories of entrepreneurial competencies, which can be associated with the traits of successful entrepreneurs (Nieuwenhuizen et al. 2008). These include the following: proactiveness: initiative and assertiveness; achievement orientation: seeing and acting on opportunities, efficiency orientation, concern for high-quality work, and systematic planning; and commitment to others: commitment to work contract, and recognising the importance of business relations (see Nieuwenhuizen et al. 2008). Other entrepreneurial traits include passion for business, locus of control, the need for independence, determination and persistence (Nieman and Nieuwenhuizen 2009).

These competencies may easily be developed in a learner through entrepreneurship education and training, primarily attainable from a schooling environment. It is an established fact therefore that entrepreneurship education and training can influence one's attitude to set up an entrepreneurial venture (Lall and Sahai 2008). Of interest, is Bolton and Thompson's (2003) argument that successful entrepreneurs in high technology and biotechnology fields are often well educated individuals. Similarly, Nieman and Nieuwenhuizen (2009) also suggest that there is a correlation between higher level of education and training, and the emergence of entrepreneurship.

\section{METHODOLOGY}

This study adopted a descriptive research design. Randomly, a sample of 132 subjects was drawn from the database of a local organisation comprising 200 youth entrepreneurs in Khayelitsha. The database was kept by the secretary of this organisation on a computer system until each member reaches the age limit of 35 years after which he/she would be removed.

Research Questionnaire: The data collection process was made possible with the help of a questionnaire, which contained closed-ended, open-ended and Likert scaled questions. A standardised and identical questionnaire for every respondent was personally administered by one of the researchers. The authors considered ethical issues in-order to have a valid study. The confidentiality and anonymity of the respondents were strictly adhered to. Anonymity is protected when the subject's identity cannot be linked with personal responses and confidentiality is the management of private information by the researcher in order to protect the subject's identity (Fouka and Mantzorou 2011). Respondents were invited to participate in the study at their own will. Guarantees given included the right to withdraw at any point during the data collection process. Informed consent means that participants exercise their rights as autonomous persons to voluntarily accept or refuse to participate in a study (Orb et al. 2001)

The questions asked brought forth information related to demographics of the participants as well as their perceptions of entrepreneurship education and training in the growth of their businesses.

Reliability of the Questionnaire: A test retest reliability evaluation was conducted on instrument of the study, as Bless et al. (2006) suggest its importance for validity and reliability purposes. A total of 10 questionnaires were initially administered to ten subjects of the study to measure consistency in the use of an instru- 
ment. The main purpose for this endeavour was to determine if the instrument would be able to produce similar results in two trials. Hence, after an interval of a couple of weeks, another set of questions comprising questionnaires identical to the previous ones, were administered among the same subjects. The obtained responses in those two occasions were assessed for consistency, and seven of them were correlated, as they were able to produce highly related results. Afterwards, slight adjustments on the instrument were made to enhance its reliability.

Data Analysis: The population for the study was chosen as a result of the belief that it would supply valuable and relevant information to the study, as the subjects reside in different parts of the township. Among other measures that were used to analyse the data, a Statistical Package for Social Sciences (SPSS version 21) software was included. A total of 77 questionnaires was returned and utilised. A response rate of 58.3\% for the study was achieved. The next section deals with the findings of the study.

\section{FINDINGS AND DISCUSSION}

Findings regarding the perceptions of youth entrepreneurs to entrepreneurship education and its importance in the success of a business venture, in Khayelitsha, are presented below. Each finding is followed by followed by the relevant discussion.

\section{Description of the Characteristics of Participants}

Results for participants’ age groups show that a majority of Khayelitsha youth entrepreneurs $(46.8 \%)$ consisted of those who were between the ages $26-30$ years, followed by $40.3 \%$ who were between the ages 31-35, while, a mere $13 \%$ of participants represented those who were between the ages 21-25. Based on research findings, a large percentage (72.7\%) of participants were males and the rest (27.3\%), were females. The findings on the highest level of education for participants revealed that $80.5 \%$ of participants achieved tertiary level, followed by $16.9 \%$ of those who matriculated. Only a few participants $(2.6 \%)$ managed to study up to high school level. Considering the number of years the businesses had been in operation, the study found that $63.6 \%$ of the businesses sampled had been around for between 1-3 years, followed by $20.8 \%$ of those which had existed between 3-5 years. 9.1\% represented new businesses that had operated for less than a year. Only 6.5\% represented businesses, which had operated for more than 5 years.

\section{Influence of Entrepreneurship Education and Training on the Participants'Ability to Start-up a Business}

With respect to this questionnaire item, we found that $44.2 \%$ of the participants disagreed that entrepreneurship education and training enabled the setting up of their businesses, while $42.9 \%$ indicated otherwise. $10.4 \%$ strongly agreed, while a mere $2.6 \%$ of the participants strongly disagreed with the statement (see Table 1). Indicatively, for some participants, entrepreneurship education and training did not enable the setting up of their businesses, while others felt that it actually did. Even though the specific field of study for each participant was not asked, they indicated that not all of them were exposed to entrepreneurship/business management courses at a schooling environment while still studying.

Table 1: Influence of entrepreneurship education and training among the participants

\begin{tabular}{|c|c|c|c|c|c|}
\hline $\begin{array}{l}\text { Resp } \\
\text { categ }\end{array}$ & $\begin{array}{l}\text { nse } \\
\text { pries }\end{array}$ & $\begin{array}{l}\text { Frequ- } \\
\text { ency }\end{array}$ & $\begin{array}{l}\text { Per- } \\
\text { cent }\end{array}$ & $\begin{array}{l}\text { Valid } \\
\text { per- }\end{array}$ & $\begin{array}{l}\text { Cuти- } \\
\text { lated }\end{array}$ \\
\hline & Strongly agree & 8 & 10.4 & 10.4 & 10.4 \\
\hline & Agree & 33 & 42.9 & 42.9 & 53.2 \\
\hline Valid & Disagree & 34 & 44.2 & 44.2 & 97.4 \\
\hline & Strongly & 2 & 2.6 & 2.6 & 100.0 \\
\hline & Disagree & & & & \\
\hline & Total & 77 & 100.0 & 100.0 & \\
\hline
\end{tabular}

These findings are related to Ndedi's (2009) argument that opportunity recognition may not only occur for entrepreneurship/business students, but also for students from other disciplines. Hence, Lowergren (2006) in Ndedi (2009) argues that students from other disciplines may require the same skills as business students. Therefore, the finding in this study corroborate Ndedi's (2009) finding that entrepreneurship should be introduced in all disciplines at tertiary school environment and be implemented at all levels. This is very important, as it can be argued that in South Africa, most entrepreneur- 
ship/business students do not possess technical skills, whereby they can be hands-on and create as well as innovate new products or services, as opposed to that of engineering, information and design students, who might be balancing theoretical knowledge with practical skills. Creativity and innovation capabilities are among core attributes of an entrepreneur. For instance the well-known entrepreneurs such as Bill Gates of Microsoft, Michel Dell of Dell Computers, Steve Jobs of Apple, Andy Grove of Intel, Mark Zuckerberg of Facebook, and others, did not rely on theoretical knowledge, but rather creativity and innovation capabilities to startup businesses. The mentioning of these wellknown entrepreneurs from information-intense economies is owed to the fact that today's youths are likely to be fascinated by the global trends, through media.

\section{Participants' Perceptions of the Role of Entrepreneurship Education and Training in the Business Success}

With respect to this questionnaire item, all the participants indicated that entrepreneurship education and training could play a big role in the success of any business (see Table 2). This finding is very important in this study, as it answers the research question. This result also aligns with what the literature argues; that entrepreneurship education and training are crucial to the success of a business venture (Nieuwenhuizen and Groenewald 2008). Isaacs et al. (2007) emphasize that in spite of the fact that in isolation, education cannot completely prepare entrepreneurs to be successful business owners, it however increases the chances of success in the business. Evidence can be found in the growing number of new firms in the US which research linked to entrepreneurship education (Ndedi 2009). Hence, Sandrock (2011) suggests that university graduates and matriculants

Table 2: Role of entrepreneurship education and training in business success

\begin{tabular}{|c|c|c|c|c|c|}
\hline \multicolumn{2}{|c|}{$\begin{array}{l}\text { Response } \\
\text { categories }\end{array}$} & $\begin{array}{l}\text { Frequ- } \\
\text { ency }\end{array}$ & $\begin{array}{l}\text { Per- } \\
\text { cent }\end{array}$ & $\begin{array}{l}\text { Valid } \\
\text { per- } \\
\text { cent }\end{array}$ & $\begin{array}{l}\text { Cumu- } \\
\text { lated } \\
\text { percent }\end{array}$ \\
\hline \multirow{3}{*}{ Valid } & Strongly agree & 56 & 72.7 & 72.7 & 72.7 \\
\hline & Agree & 21 & 27.3 & 27.3 & 100.0 \\
\hline & Total & 77 & 100.0 & 100.0 & \\
\hline
\end{tabular}

should be equipped with proper entrepreneurial skills, so as to enable the creation of more jobs, as opposed to the seeking of paid employment.

Ladzani and Van Vuuren (2002) also agree. They are of the strong opinion that entrepreneurship training should be regarded as the basic requirement for setting up and managing a business venture.

\section{Entrepreneurial Skills as a Catalyst for Success in Business Ventures}

With regard to whether the participants of the study perceive entrepreneurial skills as a catalyst for success in business, one gathers that a large proportion of the participants (53.2\%) strongly agreed that entrepreneurial skills would boost chances of success in their businesses, while 46.8 percent agreed (see Table 3 ). This finding suggests that participants in this study considered entrepreneurial skills as the most fundamental competencies, which are a requisite for the success of any entrepreneurial venture. As far as this study is concerned, economies, particularly the industrialised ones have acknowledged entrepreneurship education and training, as a major propeller of any economy. Isaacs et al. (2007) add that through the influence of entrepreneurship education and training, the emergence and sustenance of entrepreneurial ventures take place.

Table 3: Entrepreneurial skills as a catalyst for success in business

\begin{tabular}{|c|c|c|c|c|c|}
\hline \multicolumn{2}{|c|}{$\begin{array}{l}\text { Response } \\
\text { categories }\end{array}$} & $\begin{array}{c}\text { Frequ } \\
\text { ency }\end{array}$ & $\begin{array}{l}\text { Per- } \\
\text { cent }\end{array}$ & $\begin{array}{l}\text { Valid } \\
\text { per- } \\
\text { cent }\end{array}$ & $\begin{array}{c}\text { Cumu- } \\
\text { lated } \\
\text { percent }\end{array}$ \\
\hline \multirow{3}{*}{ Valid } & Strongly agree & 41 & 53.2 & 53.2 & 53.2 \\
\hline & Agree & 36 & 46.8 & 46.8 & 100.0 \\
\hline & Total & 77 & 100.0 & 100.0 & \\
\hline
\end{tabular}

Therefore, without entrepreneurship education, it may be difficult for entrepreneurs to obtain entrepreneurial competencies, which according Van Rensburg (2010) can be learnt from a schooling environment.

\section{Importance of Managerial Skills in the Success of an Entrepreneurial Venture}

With respect to this questionnaire item which was set out to establish participants' percep- 
tions of the importance of managerial skills in the success of an entrepreneurial venture, we received a unanimous response from the participants which affirmed that managerial skills would boost the chances of success in their businesses. Similar to the previous results on the importance of entrepreneurial skills, managerial skills are as important for an entrepreneur. Similarly, these findings could be related to the argument made by Van Rensburg (2010) that in order to achieve entrepreneurial performance, entrepreneurs should focus on developing their business and entrepreneurial skills. This could also be in line with the claim made by Burke (2006) that an entrepreneur should consider a number of management techniques in his portfolio of management skills in order to effectively manage a new business venture, namely project management, small business management, team building and leadership, and risk management skills. Participants also indicated that lack of business managerial skills such as finance, human resources and marketing skills were among hindering factors, which threaten the success of their businesses. Therefore, without formal entrepreneurship/business management and training it could be difficult for some of these youth entrepreneurs to manage their businesses successfully. Admittedly, some of the youth entrepreneurs who participated in the study revealed that they had no formal business education or training.

\section{CONCLUSION}

To conclude, the importance of entrepreneurship education and training in particular for the well-being of the youth cannot be overemphasised. Interestingly, despite the fact that a majority of participants in the study achieved tertiary education, almost half of them did not pursue entrepreneurship/business related education, yet they were either pushed or pulled by their circumstances into venturing in business. This somewhat confirms the findings of several studies on entrepreneurship initiatives. Interestingly participants felt that entrepreneurship education and training may not only influence an individual to set up his/her own business, but may also result in the optimum performance of the business, owing to the learned entrepreneurial skills. Again, business managerial skills were perceived to be quite as imperative as entrepre- neurial skills in the running and performance of a business venture. Therefore it is advisable that an entrepreneur should possess business managerial skills to enable him deal with the daily operations of the business. In addition, literature suggests that there are other invaluable competencies, which may be incorporated into the portfolio of an entrepreneur to aid the performance of his business venture, such as project management and emotional intelligence. Therefore, entrepreneurs should also equip themselves with such skills through education. On the basis of these concluding remarks, it is safe to say that there is indeed a link between entrepreneurship education and business success.

As have been articulated by researches on South African entrepreneurship, current and future predictions of youth unemployment in South Africa and elsewhere highlight the demand for a pool of entrepreneurs, especially youth entrepreneurs. There have also been warnings that on the basis of the dynamic labour market in South Africa, a lot of young people will not find jobs after completing their studies. Therefore, measures to enhance youth engagement in entrepreneurial activities, in particular those who have acquired entrepreneurship education from college/university should emerge. This could be achieved if entrepreneurs with good business plans receive preferential business assistance from private and public stakeholders. The assistance may be in the form of finance, mentoring, and business counselling.

\section{RECOMMENDATIONS}

It is necessary to foster a culture of entrepreneurship among the youth, particularly because some youth entrepreneurs might be as creative and innovative, but lack formal education in entrepreneurship/business management. Therefore, support structures such as the National Youth Development Agency (NYDA), the Department of Trade and Industry (DTI), and other agencies should work towards closing this gap to assist with the know-how of successfully operating a business venture.

There are many other townships with the same characteristics as Khayelitsha that can benefit from a study of this nature with an even more statistics-intensive analysis. This can help to generate deeper insights into the challenges and prospects of youth entrepreneurship in 
Khayelitsha specifically and South Africa in general. It is also important to point out that entrepreneurship education may not only be obtained from a formal academic institution. Customised and affordable short courses on business related topics can be organised for these township businesses. In fact, the short courses may be designed in such a way that they bear credits to enable progression to a higher qualification. This may stimulate interest in the pursuit of training and development. The short courses can also be funded by government agencies and or private institutions in the form of corporate social responsibility.

\section{REFERENCES}

Alberti F, Sciascia S, Poli A 2004. Entrepreneurship education: notes on an ongoing debate. In: Proceedings of the 14th Annual IntEnt Conference, University of Napoli Federico II, Italy, pp. 4-7.

Awogbenle AC, Iwuamadi KC 2010. Youth unemployment: Enterpreneurship development programme as an intervention mechanism. African Journal of Business Management, 4(6): 831-835.

Bless C, Higson-Smith C, Kagee A 2006. Fundamentals of Social Research Methods. An African Perspective. Cape Town: Juta.

Bolton B, Thompson J 2003. The Entrepreneur in Focus Achieve Your Potential. London: Thompson Learning.

Burke R 2006. Entrepreneurs Toolkit. Cape Town: Burke Publishing.

Davey T, Plewa C, Strung M 2011. Entrepreneurship perceptions and career intentions of international students. Education+Training, 53(5): 335-352.

Davies TA 2001. Entrepreneurship development in South Africa: redefining the role of tertiary institutions in a reconfigured higher education system. South African Journal of Higher Education, 15(1): 32-9.

Dawson C, Henley A 2012. "Push” versus “pull” entrepreneurship: an ambiguous istinction?. International Journal of Entrepreneurial Behaviour \& Research, 18(6): 697-719.

Fatoki O, Chindoga L 2011. An Investigation into the obstacles to youth entrepreneurship in South Africa. International Business Research, 4(2): 161169.

Fouka G, Mantzorou M 2011. What are the Major Ethical Issues in Conducting Research? Is there a Conflict between the Research Ethics and the Nature of Nursing? From <http://www.hsj.gr/volume5/ issue1/512.pdf $>$ (Retrieved on 5 October 2013).

Gordhan P 2012. 2012 Budget Speech. Pretoria: Communications Unit National Treasury.

Herrington M, Kew J, Kew P 2009. Tracking Entrepreneurship in South Africa: A GEM Perspective. From <www.gsb.uct.ac.za/files/Gembook2009.pdf> (Retrieved on 10 June 2011).
Hughes M, Patterson LB, Terrell JB 2005. Emotional Intelligence in Action: Training and Coaching Activities for Leaders and Managers. San Fransisco: Pfeiffer.

Iqbal A, Melhem Y, Kokash H 2012. Readiness of the university students towards entrepreneurship in Saudi Private University: An exploratory study. European Scientific Journal, 8(15): 109-131.

Isaacs E, Visser K, Friedrich C, Brijal P 2007. Entrepreneurship education and training at the Further Education and Training (FET) level in South Africa. South African Journal of Education, 27(4): 613629.

James W 2012. Youth entrepreneurship is the key to future growth. From <http://www.da.org.za/newsroom. htm?action=view-news-item\&id= 10383> (Retrieved on 28 March 2012).

Jesselyn Co M, Mitchell B 2006. Entrepreneurship education in South Africa: A nationwide survey. Education+Training, 48(5): 348-359.

Katz JA 2003. The chronology and intellectual trajectory of American entrepreneurship education 18761999. Journal of Business Venturing, (18): 283300.

Keat OY, Selvarajah C, Meyer D 2011. Inclination towards entrepreneurship among university students: An empirical study of Malaysian university students. International Journal of Business and Social Science, 2(4): 206-220.

Kirkwood J 2009. Motivational factors in a push-pull theory of entrepreneurship. Gender in Management: An International Journal, 24(5): 346-364.

Kume A, Kume V, Shahini B 2013. Entrepreneurial characteristics amongst university students in Albania. European Scientific Journal, 9(16): 206-225.

Kuratko DF 2014. Introduction to Entrepreneurship. $9^{\text {th }}$ Edition. Canada: Cangage Learning.

Ladzani WM, Van Vuuren JJ 2002. Entrepreneurship Training for Emerging SMEs in South Africa. Journal of Small Business Management, 40: 154-161.

Lall M, Sahai S 2008. Entrepreneurship. New Delhi: Excel Books.

Laukkanen M 2000. Exploring alternative approaches in high-level entrepreneurship education: creating micro mechanisms for endogenous regional growth. Journal of Entrepreneurship and Regional Development, 12(1): 25-47.

Linan F, Rodriguez-Cohard JC, Rueda-Cantuche JM 2005. Factors affecting entrepreneurial intention levels. Paper presented at the $45^{\text {th }}$ Congress of the European Regional Science Association, Amsterdam, 23-27.

Lowergren M 2006. Entrepreneurship Education: Developing Project-based learning. National Council for Graduate Entrepreneurship, Working Paper 0151/ 2006. December.

Macaulay F 2008. Youth Microenterprise and Livelihoods: State of the Field. Washington: Making Cents International.

Mahadea D, Ramroop S, Zewohir T 2011. Assessing Entrepreneurship Perceptions of High School Learners in Pietermaritzburg, KwaZulu Natal, 14(1): 66-79.

Mensah MSB 2013. Entrepreneurship education on wholesale? Considerations on didactics and pedago- 
gy for enhanced graduate employment in Ghana. European Journal of Business and Management, 5(15): 105-113.

Mkoka S 2012. Towards integrated youth development. My Youth My Future Journal, 1(1): 2-103.

Morrow S, Pandey S, Ritcher L 2005. Where are we now and where are we going: Young people in South Africa, Johannesburg: Umsobomvu Youth Fund.

Mwangi SM 2011. The contribution of entrepreneurship education course in enhancing management skills of informal entrepreneurs. Journal of Education and Vocational Research, 2(3): 86-92.

Nafukho FM, Muyia MAH 2010. Entrepreneurship \& Socioeconomic development in Africa: A reality or myth? Journal of European Industrial Training, 34(2): 96-109.

Ndedi AA 2009. Entrepreneurship training and job creation in South Africa: Are tertiary institutions Filling the gap? Journal of Contemporary Management, 6: 463-470.

Nicolaides A 2011. Entrepreneurship - the role of Higher Education in South Africa. Educational Research, 2(4): 1043-1050.

Nieman G, Nieuwenheuizen C 2009. Entrepreneurship. A South African Perspective. Cape Town: Interpak Books.

Nieman G, Hough J, Nienwenhuizen C 2003. Entrepreneurship - A South African perspective. Pretoria: Van Schaik Publishers.

Nieuwenhuizen C, De Beer AA, Zeelle Z, Groenewald D, Watson H, Rossouw D, Jacobs H 2008. Entrepreneurial Skills. Cape Town: Creda communications.

Nieuwenhuizen C, Groenewald D, 2008. Entrepreneurs' learning preferences: A guide for entrepreneurship education. Acta Commercii, 128-144.

Nigerian Education Research and Development Council 2004. National Policy on Education $4^{\text {th }}$ Edition, Lagos: NERDC Press

Orb A, Eisenhauer L, Wynaden D 2001. Ethics in Qualitative Research. From <http://www.columbia.edu/ $\sim$ mvp19/RMC/M5/QualEthics.pdf > (Retrieved on 23 April 2013)

Owusu-Ansah W, Fleming P 2002. The impact of Entrepreneurship Education on Business Venturing: A Longitudinal Survey of Irish Graduates. Paper delivered at IntEnt2001 Internationalizing Entrepreneurship Education and Training Conference, 91-111.

Peterman NE, Kennedy J 2003. Enterprise education: influencing students' perceptions of entrepreneurship. Entrepreneurship Theory and Practice, 129-144.
Pittaway L, Cope J 2007. Entrepreneurship education: A systematic review of the evidence. International Small Business Journal, 25(5): 479-510.

Postigo S, Tamborini MF 2002. Entrepreneurship education in Argentina: the case of San Andres University. Paper presented at the Internationalizing Entrepreneurship Education and Training Conference - IntEnt 2002, Malaysia, July.

Sandrock J 2011. National Report into the state of entrepreneurship. Economic Growth = Growing Entrepreneurship. From <http://www.ideate.co.za/ 2011/0/3/22/economic-growth-growing-entrepreneurship/> (Retrieved on 7 April 2011)

Shay D, Wood E 2004. Pilot impact evaluation of the Business Ventures programme on the entrepreneurial attitudes of school learners - Final Report. Cape Town: UCT Centre for Innovation \& Entrepreneurship.

Thomas N, Barra O 1994. Entrepreneurship education and training programmes: A review evaluation-Part 1. Journal of European Industrial Training, 18(8): 3-12

Van Rensburg LJ 2010. National Report into the state of entrepreneurship. Can Entrepreneurship be Taught/Learned? From <http://www.ideate.co.za/ 2010/10/20/can-entrepreneurship-be-taught/ learned/> (Retrieved on 7 April 2011)

Volery T, Mueller S 2006. A conceptual framework for testing the effectiveness of entrepreneurship education programmes towards entrepreneurial intention. 51st ICSB World Conference Melbourne, Australia.

Von Broembsen M, Wood E, Herrington M, Shay D, Sheppers R 2005. Global Entrepreneurship Monitor, South African Report, Cape Town: University of Cape Town.

Western Cape Youth Report 2008. Western Cape Status Report of the Youth Report. From <http://www. gsb.uct.ac.za/files/2008Western Cape Statusof theYouthReport.pdf $>$ (Retrieved on 27 August 2011).

Xesha D, Iwu CG, Slabbert A. 2014. Business relationships as a driver of success for small, medium, and micro enterprises (SMMEs) in South Africa. Journal of Economics, 5(1): 37-43.

Youth Business International 2009. Youth Entrepreneurship. Recommendations for Action. From <http://www.pdp.com.sv/main/archivos/publicaciones/RecommendationsforAction.pd> (Retrieved on 2 December 2011). 